\title{
Challenging oppression: how grassroots anti- racism in Berlin breaks borders
}

\section{Marco Perolini}

To cite this article: Marco Perolini (2021): Challenging oppression: how grassroots anti-racism in Berlin breaks borders, Ethnic and Racial Studies, DOI: 10.1080/01419870.2021.1966066

To link to this article: https://doi.org/10.1080/01419870.2021.1966066
( ) 2021 The Author(s). Published by Informa UK Limited, trading as Taylor \& Francis Group

\section{曲 Published online: 16 Aug 2021.}

\section{एव \\ Submit your article to this journal $\pi$}

\section{Цll Article views: 77}

Q View related articles

View Crossmark data $\asymp$ 


\title{
Challenging oppression: how grassroots anti-racism in Berlin breaks borders
}

\author{
Marco Perolini \\ Department of Sociology, Goldsmiths College, London, UK
}

\begin{abstract}
In recent years, the successful anti-migrant mobilization of populist radical right parties and movements in Germany has stimulated the anti-racist struggle. This article investigates the anti-racism of grassroots organizations that contest border regimes in Berlin. While grassroots anti-racism also intends to combat the ideology of populist radical right parties, it contributes distinctively to the debates on racism, colonialism and border regimes. Specifically, grassroots antiracism sheds light on the mechanisms through which border regimes oppress and racialize migrants. Crucially, by acknowledging the imbrication between historical racial inequalities and border regimes, grassroots organizations weave an anti-racist struggle against border regimes that is emancipatory for racialized migrants. I contend that grassroots anti-racism contributes to tackling the pervasive historical amnesia (Hall, S. 2000. "Conclusion: The Multicultural Question." In Un/settled Multiculturalisms: Diasporas, Entanglements, 'Transruptions', edited by B. Hesse. Zed Books) regarding colonialism and the role of racism in the construction of the German nation.
\end{abstract}

ARTICLE HISTORY Received 6 February 2021; Accepted 3 August 2021

KEYWORDS Migration; racism; anti-racism; oppression; colonialism; far right

On 10 March 2018 I marched through the streets of Cottbus, a small city located $100 \mathrm{~km}$ from Berlin that had been swept by racist attacks and anti-refugee protests since the beginning of the year. Women in Exile and friends, a feminist grassroots organization opposing border regimes, organized the protest to mark International Women's Day. ${ }^{1}$ Under the motto "Women united against racism and injustice", a few hundred activists filled the gloomy and empty streets of Cottbus in that chilly late winter morning with their powerful slogans against racism and in support of residence rights for all migrants in Germany.

Shortly after the protest, anti-refugee politics reached a new climax in Germany with the appointment of Horst Seehofer (the leader of the Christian

CONTACT Marco Perolini mpero002@gold.ac.uk; in linkedin.com/in/marco-rolini2b9a137 @esteban80paris

This article has been corrected with minor changes. These changes do not impact the academic content of the article.

\section{(c) 2021 The Author(s). Published by Informa UK Limited, trading as Taylor \& Francis Group}

This is an Open Access article distributed under the terms of the Creative Commons Attribution-NonCommercial-NoDerivatives License (http://creativecommons.org/licenses/by-nc-nd/4.0/), which permits non-commercial re-use, distribution, and reproduction in any medium, provided the original work is properly cited, and is not altered, transformed, or built upon in any way. 
Social Union, CSU) as federal Minister of the Interior. Formerly Minister-President of Bavaria and well known for his hawkish views on migration (Barker 2017), Seehofer further limited family reunification, curtailed the rights of asylum seekers, and facilitated deportations. ${ }^{2}$ His appointment and the tightening of border regimes occurred against the backdrop of the relentless rise of populist radical right parties and movements in Germany (Rucht 2018). ${ }^{3}$

Women in Exile and friends and many other grassroots organizations opposing border regimes challenge the most visible and spectacular forms of racism, which include racist violence and the successful use of racist and anti-migrant frames by populist radical right parties and movements. However, in this article, I contend that the anti-racism of grassroots organizations is more far-reaching than the anti-racism primarily oriented towards opposing populist radical right parties and movements, which is embraced by new coalitions that emerged in 2018. Specifically, grassroots anti-racism contributes to tackling the historical amnesia (Hall 2000) which has erased race, institutional racism, and the colonial past from public debate in Germany. I argue that through their collective mobilization, grassroots organizations bring to the fore the imbrication between racism, border regimes, and the state; they expose and contest the role of border regimes in reproducing a system of relations based on oppression that has its origin in colonialism. As we shall see, grassroots anti-racism enables the emergence of emancipatory claims that challenge the oppression of racialized migrants in Germany.

To develop my main arguments, the rest of this article is organized as it follows: first, I contextualize grassroots anti-racism opposing border regimes against the backdrop of the rise of populist radical right parties and movements in Germany after 2014, which, in turn, has generated an increased social movement activity. Second, I theorize different forms of anti-racism, their intersections and tensions, and I provide some information about the methods through which I collected my data. Then, I explain how grassroots anti-racism is grounded in the experiences of racialized migrants and their interpretation of the oppressive mechanisms embedded in border regimes. In the fourth section, I contend that grassroots organizations frame these mechanisms of oppression as associated with colonial histories. In the last section, I conceptualize the connections between the anti-racism of grassroots organizations and the emancipatory potential of the alternative solutions to current border regimes that they collectively elaborate. I then draw some conclusions regarding the emancipatory potential of grassroots anti-racism and the knowledge that it produces about racism and border regimes.

\section{Radical right politics, racism, and increased social movement activity in Germany}

The rise of the recorded number of people claiming asylum in Germany as of 2014 has been accompanied by the proliferation of solidarity initiatives, 
which are part of the so-called Willkommenskultur, or welcome culture (Hamann and Karakayali 2016). At the same time, anti-migrant and antirefugee movements and parties have successfully mobilized xenophobic and racist frames by presenting asylum seekers as a threat to security, social welfare, and cultural identity (Rucht 2018).

In 2014, the movement PEGIDA (Patriotic Europeans against the Islamisation of the Occident) started staging large protests in Dresden and other cities (Hartz 2019). In 2017, the populist radical right party Alternative for Germany (AfD) entered the Federal Parliament for the first time, after obtaining $12.6 \%$ of the votes in the elections (Lees 2018). In the same years, racist violence targeting asylum seekers and asylum shelters soared (Amnesty International 2016; Benček and Strasheim 2016).

Grassroots organizations such as Women in Exile and friends contest the rise of populist radical right parties and movements by for example organizing the protest in Cottbus that I referred to in the introduction. Grassroots activism opposing specific aspects of border regimes, including asylum laws that required asylum seekers to live in segregated asylum shelters, is not a new phenomenon as it already emerged in the 90s when asylum seekers organized collective actions in refugee shared accommodation, in particular in Eastern Germany. For example, the Voice Refugee Forum was founded in 1994 in a shared accommodation in Thuringia (Jakob 2016; Odugbesan and Schwiertz 2018). Women in Exile and friends was founded in 2002 to combat racist asylum policies and gender-based discrimination faced by refugee women. These grassroots organizations also participated in the protest camp in Oranienplatz in Berlin, which provided visibility for their struggles against border regimes from 2012 to 2014 (Langa 2015; Odugbesan and Schwiertz 2018).

The successes reaped by radical right parties and movements after 2014 triggered an enhanced social movement activity, including the emergence of new coalitions such as Unteilbar. The coalition Unteilbar is composed of a variety of organizations including grassroots organizations contesting border regimes such as Women in exile and friends, trade unions, NGOs as well as diaspora and Black grassroots organizations such as Initiative Schwarze Menschen in Deutschland (ISD). Unteilbar has raised concerns about the fact that mainstream parties, such as the Christian Social Union and its leader Horst Seehofer, pander to the racist frames of populist radical right parties and movements. The 2018 manifesto, through which the coalition publicized its demands, emphasized:

A dramatic political shift is taking place: racism and discrimination are becoming socially acceptable. What yesterday was considered unthinkable and unutterable has today become a reality. Humanity and human rights, religious freedom, and the rule of law are being openly attacked. This is an attack on all of us. ${ }^{4}$ 
The coalition Unteilbar frames radical right populist parties and movements as the main promoters of racist ideologies; its mobilization aims to contain racism and to evict it from mainstream politics. Thus, the coalition reproduces the association between racism and the far-right that has been dominant in Germany after World War II and that has eliminated the notions of race and racism from public discourse as a way to take distance from the Nazi past (Müller 2011). The coalition does not acknowledge the racializing impact of border regimes. Nor does it establish a connection between border regimes and the German colonial legacy. In contrast, I contend in this article, grassroots organizations identify the state and border regimes as mechanisms reproducing racism. The anti-racism of grassroots organizations is crucial in a context such as the German one in which institutional racism is regularly denied (Boulila and Carri 2017), and the authorities have been reluctant for a long time to recognize the colonial past and its crimes such as the genocide perpetrated in Southwest Africa, today Namibia (Boehme 2020; El Tayeb 1999). ${ }^{5}$

The anti-racism of grassroots organizations opposing border regimes plugs into the interventions of Black and diaspora activism in Germany. Since the 1980s, Black German activism and other forms of diaspora activism, for example among Turkish Germans, have contributed to emphasizing the role of racism in the construction of the German identity as a white nation (Florvil 2020; Mandel 2008). They have also contested whiteness as a defining aspect of citizenship in Germany, especially until the 1999 reform of citizenship law, which has introduced the possibility for children of foreign parents to acquire German citizenship at birth (Green 2012).

In this article, I argue that the anti-racism of grassroots organizations does not only contribute to recentring the debate about race and racism but is also emancipatory for migrants who experienced the racialization of border regimes. In contrast, initiatives such as Unteilbar frame their demands against border regimes through the idea of the right to asylum which grassroots organizations consider too limited. As we shall see, grassroots organizations collectively develop alternative solutions to current border regimes, challenging the main mechanisms that racialize migrants by restricting their mobility.

\section{Anti-racism as a method}

Anti-racism, conceived as a set of practices that seek to confront, challenge, and eradicate racism, is heterogeneous and can follow multiple approaches (Bonnett 2000). Lentin has emphasized the diverse orientations of antiracism in collective struggles; anti-racism can for example be geared towards opposing everyday institutional racism or rather focusing on the more spectacular opposition to the far-right (Lentin 2008, 316). Antifascism, 
which is the opposition to the far-right, may underestimate the fact that racism is embedded and diffused in various state institutions, including in states that are not overtly racist (Battacharyya, Virdee, and Winter 2020).

The complexity and diversity of anti-racism also stem from the varied and complex forms and practices of racism that are subject to a continuous renewal (Bulmer and Solomos 2018). Racism can be conceptualized as a social relation that exceeds a specific ideology embraced by the far-right. For example, Goldberg and Solomos conceive racism as a system of racially predicated relations based on domination and oppression (Goldberg and Solomos 2002, 4). This relational understanding of racism emphasizes the role that the construction of racial meanings plays in reproducing systems of domination and oppression and how racism intersects with other mechanisms of oppression such as those premised on class and gender (Camfield 2016; Georgi 2019; Roediger 2017). Racism cannot be seen merely as the ravings of racist subjects (Balibar 1991, 41) and as an ideology embraced by the far-right (Camfield 2016). Conceptualizing racism as a set of relations based on domination and oppression implies an analysis of the material conditions of oppression that racism produces beyond their ideological underpinning.

In proposing the notion of anti-racism as a method, Bojadžijev argues that a focus on the conflicts that racism generates, including anti-racist struggles, produces knowledge and contributes to the analysis of forms and practices of racism (Bojadžijev 2020). In this article, my starting point is the grassroots anti-racist struggle against some aspects of border regimes, more specifically asylum laws and policies. The analysis of grassroots anti-racism reveals modes and practices through which border regimes reproduce racism.

Different forms of anti-racism can intersect and overlap and are not necessarily in conflict with one another. Strategic alliances, as well as ties and connection, can indeed exist among social movement organizations characterized by different collective identities (Diani 1992; McGarry, Tramontano, and Jasper 2015). Alliances between grassroots organizations embracing an anti-racism geared towards contesting institutional racism and organizations focusing on combating the racist ideology of the far-right can emerge in a dynamic social movement setting as anti-racism can be a practice of diverse social movements and a unified front of diversity politics (Hall 1997; Lentin 2011; Lazaridis and Veikou 2017). However, I argue that the specificity of grassroots anti-racism is its role in opening up possibilities for resisting border regimes through the collective formulation of emancipatory claims that challenge the oppression faced by migrants.

This article is based on the ethnography of the movement opposing border regimes that I conducted in Berlin between January and November 2018. I carried out participant observation of the daily activities of five grassroots organizations (GROs) opposing asylum laws and policies, including two 
organizations, Corasol and Stop Deportation Group, in which activists are mostly people from the global south who have claimed asylum in Germany. Furthermore, I participated in dozens of protests organized by a variety of organizations and interviewed 37 activists who mobilized with grassroots organizations, NGOs, or large coalitions such as Unteilbar and Welcome United, a coalition of grassroots organizations.

Ethnographic approaches are crucial to understanding how migrants who mobilize with grassroots organizations interpret the mechanisms through which border regimes oppress them and how they collectively elaborate alternatives that are emancipatory precisely because they challenge those very mechanisms. I negotiated access for participant observation by conceiving my role as an active participant-observer (Johnson, Avenarius, and Weatherford 2006). I have thus provided support to activists by, for example, interpreting from English to French or helping with the organization of protests and other events. This practical support was useful to overcome the scepticism of many activists towards academic researchers. Some activists asked me to foresee a space in which some of my findings could be shared and discussed with them. I thus organized a workshop in November 2018 before leaving my fieldwork and then shared some of my findings with activists in February 2020 during a short visit to Berlin.

I have established rapport with activists by sharing my standpoint which acknowledges the imbrication between racism, border regimes, and oppression of migrants. In the grassroots organizations in which both migrants from the global south and white German activists mobilized, I often assumed a supporting role similar to the role of other white activists. However, my lack of fluency in Germany, especially at the beginning of my ethnography, prevented me from supporting migrant activists in their interactions with German asylum authorities when they needed translators; German activists often providing this type of support.

In this article, I refer to racialized activists who have migrated from the global south to Germany to claim asylum as migrants without inferring whether they are entitled to the legal status of refugee or other protection statuses. As we shall see, they all believe that they should be given residence rights in Germany as part of the emancipatory claims that they make against border regimes. I identify all the activists mentioned in this article with a pseudonym to protect their security and privacy, and in compliance with their informed consent.

\section{Restricting mobility: how border regimes oppress migrants}

Lentin has argued that anti-racism can be more or less grounded in the experiences of racialized people and that this is a crucial component 
differentiating distinct forms of anti-racism (Lentin 2008). In this section, I contend that the anti-racist politics of grassroots organizations (GROs) is based on the experiences of racialized migrants. GROs collectively interpret restrictions on mobility as among the main mechanisms through which border regimes racialize migrants. These mobility control mechanisms comprise mandatory accommodation in separated shelters and deportation.

Activists who mobilize with grassroots organizations in Berlin often refer to reception centres and shared accommodation for asylum seekers as Lager (camps), in which migrants are subject to control and often have few contacts with the external world (Fontanari 2017; Perolini 2020). Camps have been conceived as a space of exception where bare life and lack of the "right to have rights" are exposed (Agamben 1998).

When I conducted my ethnography in 2018 the authorities required migrants claiming asylum to live in a reception centre for up to six months. At the time, they could not leave the district where their designated reception centre was located for three months (this restriction is commonly known as Residenzpflicht). ${ }^{6}$ After six months, the authorities transferred people whose asylum application was still pending to a shared asylum accommodation where they could spend months, sometimes years. In 2018 grassroots organizations contested the establishment of new reception and accommodation centres, the so-called Anker centres, in which people could spend up to 24 months while waiting for their asylum claim to be processed. $^{7}$

Grassroots organizations framed camps as mechanisms of oppression and oppose them in protests. For example, Jade, a woman from Nigeria whose asylum claim was pending at the time and who lived in a camp in Bamberg (Bavaria), joined the activists' bus tour organized by Women in Exile and friends in July 2018. She framed the camp where she lived as a prison. ${ }^{8}$ In the context of a protest organized during the bus tour in the city of Nuremberg, she delivered a speech in which she emphasized:

\footnotetext{
We are living as prisoners, we are prisoners already. We are suffering in that camp, honestly, we are suffering, look at our kids, our families ... the women have no privacy ... 16 people ... one toilet, one bedroom ... we are going nowhere [...] we need help, we have come here and we go nowhere. Say "noooooo!!!' We are going to stay!
}

In her speech, Jade made an indirect reference to the threat of deportation that people faced especially after the rejection of their asylum demand. The act of staying, which Jade emphasized in her speech, precisely opposes the state's attempts to deport migrants, which constitutes yet another mechanism through which border regimes control their mobility and deny them residence rights in Germany. Grassroots organizations framed deportation as racist and as a brutal mechanism of oppression. For 
example, the press release that several GROs published ahead of a protest against all deportations that took place on 11 February 2018, emphasized:

While most people are asleep, the German border regime is carrying out its ruthless and violent practice of expulsion. For those affected, this policy has dramatic consequences, because in those places [where they are deported to] they are threatened with extreme poverty, imprisonment, forced labour, persecution and social exclusion, war, torture or death [...]. Deportations are the most brutal means of state social exclusion. Legitimized by racism, nationalism and a devaluation of poor people, people are completely subjugated and forcibly taken to countries which they obviously had a reason to leave. ${ }^{10}$

The production of illegality and the condition of deportability (De Genova 2002,2005 ) exclude racialized migrants from accessing rights and put them under enormous stress. The opposition to all deportations, which is key in the struggle of grassroots organizations against border regimes, is grounded in the experiences of racialized activists who claimed asylum in Germany. These activists often do not enjoy residence rights as many are either waiting for their asylum claim to be assessed or hold a duldung ${ }^{11}$, a precarious legal status that entails only a temporary suspension of deportation. As they often are from countries such as Kenya or Cameroon, the authorities consider that their asylum claims have low chances of success. Furthermore, they enjoy only limited legal rights. For example, they do not have access to family reunification and could work only in few circumstances. ${ }^{12}$ German border regimes embed multiple legal statuses or figures of migration (Casas-Cortes et al. 2015; Scheel and Ratfisch 2014) which are associated with a stratified access to rights (Morris 2003).

Activists often talked about the anxiety caused by their precarious legal status during the weekly meetings of grassroots organizations. Robert, a young activist who mobilized with Corasol and who held a duldung, often shared concerns regarding his precarious residence status in the context of the weekly meetings of the organization. In February 2018, Robert enquired if someone could accompany him to an appointment with the Ausländerbehörde [Foreigners' Office] for the renewal of his duldung. Robert told me after the meeting:

I would like someone to come with me because the outcome of the appointment is unpredictable and I fear they could send me back to any African country without having the possibility of informing anyone. ${ }^{13}$

Grassroots organizations frame compulsory residence in camps as a measure that facilitates deportation through control and surveillance. Deportations are conducted through unannounced police raids that often take place at night in camps. For this reason, many racialized activists with precarious legal status often look for alternative and safe accommodation. Many activists whom I met had left their camps in Brandenburg (the state surrounding 
Berlin) and moved to Berlin. While their mobilization, especially in visible repertoires such as protests, is associated with risks such as racial profiling by police, it also provides them with opportunities to access a wide network of solidarity in Berlin, including housing options provided by German activists living in flatshares or by grassroots organizations.

In this section, I have argued that grassroots organizations interpret mobility control mechanisms as key modalities through which border regimes oppress migrants. Migrants who claim asylum cannot move freely in Germany and they have to live in separated asylum shelters under the constant gaze of state authorities. The anti-racist struggle that grassroots organizations weave against border regimes is grounded in the experiences of racialized activists whose mobility is restricted, who hold a precarious legal status and who have access to limited legal rights. This struggle highlights the mechanisms through which border regimes produce relations of domination and oppression based on characteristics such as race, migration status and citizenship that become perceived as fixed and immutable (Camfield 2016). As we shall see in the next section, grassroots anti-racism also emphasizes how these oppressive mechanisms embedded in border regimes are not new as they stem from colonial histories.

\section{Grassroots anti-racism framing border regimes as the continuation of colonialism}

In this section, I argue that the anti-racism of grassroots organizations is premised on the recognition of the role of the state and of border regimes in reproducing racism as a social relation based on domination and oppression. Grassroots organizations ground their struggle in the acknowledgement of the connections between colonial histories, global racial inequalities and border regimes. The anti-racism of grassroots organizations reveals racist mechanisms embedded in border regimes beyond the racist ideology underpinning the anti-migrant agenda of populist radical right parties and movements.

Scholars have emphasized the role of racism in the construction of nation states in the nineteenth century as well as in the building of the European expansionist colonial empire (Goldberg 2002). Border regimes, as complex systems that regulate the exclusion and the disenfranchisement of migrants (Tsianos and Karakayali 2010), are also mechanisms that reproduce oppression at the global level. More specifically, some scholars have conceived border regimes as devices that maintain the system of racial inequalities stemming from colonialism (Erel, Murji, and Nahaboo 2016). In this respect, border regimes can be seen as the continuation of the colonial project (Sayyid 2017). 
Grassroots organizations opposing border regimes frame racism as embedded in state institutions such as the police. In 2018, they target Seehofer, the newly appointed Minister of Interior, as they see his policies as pandering to the racist, anti-migrant ideology of populist radical right parties. Moreover, they frame his policies as strengthening some of the key mechanisms of oppression of migrants, including the compulsory residence in reception centres. On 20 June, several grassroots organizations staged a protest in front of the Federal Parliament building in which they harshly criticized the new policies, which included the establishment of new reception centres for asylum seekers, the so-called Anker centres, and the limitations on family reunification. On that day, Joanne, an activist from Kenya whose asylum application had been rejected pointed out in her speech:

We don't know yet the complete plan of Mr Seehofer but we know his intentions. He wants to spread the Anker centres throughout the country, he wants to be remembered as a macho man who brought back Germany to order, he has a right-wing agenda, which is racist, sexist and misogynist. ${ }^{14}$

Targeting the Minister of Interior is a point of intersection between grassroots anti-racism and new coalitions such as Unteilbar, which identified the appointment of Horst Seehofer as a shifting point because of his hawkish views on migration and asylum, which flirted with those promoted by parties such as Alternative for Germany. Grassroots organizations such as Women in Exile and friends and Corasol joined the coalition Unteilbar and participated in the large protest that Unteilbar organized in Berlin on 13 October 2018.

However, grassroots organizations do not only see racism and the state as imbricated but they also frame border regimes as reproducing global racial inequalities that have their origin in colonialism. Activists contrast the restricted mobility of migrants in Germany with the unbridled mobility of European colonizers that produced histories of impoverishment and exploitation. In an interview, Charles, an activist from Cameroon who at the time had a precarious legal status in Germany, explained to me the link between colonialism, the impoverishment of Cameroon and migration. He emphasized:

There are people in Africa who flee because, despite their countries being rich in natural resources, they have been impoverished by ill-conceived policies [...] Germany was the first country to colonize Cameroon. They colonized us from 1884 until the First World War. They built the railway by relying on the forced labour of our ancestors, in view of plundering our natural resources ... gold, diamonds and oil. ${ }^{15}$

The grassroots mobilization against border regimes challenges the injustices that people from the global South have been suffering for centuries. For example, the manifesto that Welcome United published ahead of the antiracist march organized in Hamburg in September 2018 called for putting an end to global injustice and emphasized: 
For hundreds of years, some countries have robbed other countries' resources. Slave trade, natural resources, appalling labour and corrupt governments. The wealth of the west is built upon exclusion and exploitation. Europe continues to export a rampant predatory capitalism which kills every day. People escape to Europe because they are left with nothing and want to save their lives. ${ }^{16}$

Grassroots organizations opposing border regimes engage in an anti-racist resistance emphasizing that racism is a historically-produced system of relations based on the oppression of racialized migrants, which border regimes contribute to reproducing. Their anti-racism intersects with antiracism practices of Black and diaspora activism in Germany, which have highlighted the role of racism in the construction of the German nation and identity (Florvil 2020; Mandel 2008). The anti-racism of grassroots organizations opposing border regimes establishes connections between past and present mechanisms through which racism is produced and emphasizes the continuous role of borders in the construction of relations based on oppression.

\section{Anti-racism and emancipatory alternatives to current border regimes}

In this section, I argue that despite their overlapping, the anti-racism of grassroots organizations is distinctive from the anti-racism mainly oriented towards opposing populist radical right parties and movements. Specifically, I contend that grassroots anti-racism is associated with the formulation of alternatives solutions to current border regimes that are emancipatory for racialized migrants.

Alternatives solutions to current border regimes are often embedded in the slogans that grassroots activists voice during protests. For example, on 10 March 2018 the activists who animated the march that Women in Exile and friends organized in Cottbus repeatedly sang: "Freedom of movement, freedom of residence, right to stay, right to come, right to go". They also repeatedly chanted another slogan "Kein Mensch ist illegal, bleiberecht überall" [Nobody is illegal, right to stay everywhere].

Grassroots organizations frame their demands against border regimes through the notion of the right to stay. The manifesto for the anti-racist march of Welcome United, which took place on 30 September 2018 in Hamburg, framed the right to stay as necessary to terminate the fear, insecurity and uncertainty experienced by all people who had claimed asylum in Germany. The manifesto called for the end of deportation and unconditional residence rights for everyone. ${ }^{17}$

Activists who mobilize with grassroots organizations interpret the notion of the right to stay as stemming from the idea of universal and unrestricted freedom of movement. Carmela, a European activist with residence rights, 
explained to me that the slogan "right to come, right to stay and right to go", covered the multiple dimensions of freedom of movement. In an interview, Carmela emphasized:

Freedom of movement evokes the idea that you have the right to cross a border to go to another country. The right to come, the right to stay and the right to go is a more articulated idea than freedom of movement. It means that you can leave the place where you live, you can come back or you can stay in another place where you feel safe, if you feel comfortable and you want to be there during your whole life. ${ }^{18}$

The connection between the right to stay and freedom of movement is crucial to fully understand the emancipatory dimension of the anti-racist struggle that grassroots organizations weave against border regimes. Freedom of movement entails the opposition to camps through which the state exercises control on the mobility of racialized migrants who claim asylum in Germany. Their mobility is restricted as they cannot move outside the district in which the reception centre where they live is located as I discussed in the third section of this article. Furthermore, demanding the right to stay implies the end of deportation, a risk that many activists with a precarious legal status face. In other words, freedom of movement is the aspiration of racialized migrants for living free from oppressive mobility control mechanisms.

Freedom of movement is an essential component of the alternative solutions to current border regimes that grassroots organizations collectively elaborate. These solutions emerge from the anti-racism of grassroots organizations that is oriented towards challenges those mechanisms that they interpret as reproducing the oppression of migrants based on characteristics that are made perceived as inherited such as race, nationality and migration status. In my interview with Julia, an activist from Kenya who had a precarious legal status, the connection between unrestricted freedom of movement and anti-racism interpreted as the opposition to a system based on domination and oppression stood out. Julia emphasized:

[Freedom of movement] is a demand for those people who have less privileges. There are people with privileges who can go everywhere with their passport without fighting, they can get the visa in the country where they are going [to reside] or travel worldwide [...] Everybody should be allowed to move because people move for different reasons, not only for political reasons... They move because of social issues, climate change and so on. ${ }^{19}$

Julia's last point refers to racialized mobility hierarchies that entail different opportunities and restrictions for enjoying freedom of movement. These hierarchies mirror legal hierarchies and stratified access to legal rights for people who claim asylum in Germany. For example, those holding a precarious legal status such as the duldung do not have access to residence rights or family 
reunification. The right to stay, as a component of universal freedom of movement, is an overarching principle of equality. Grassroots organizations frame the right to stay as a principle that could free racialized migrants from a system in which freedom of movement, residence rights and other legal rights are made dependent on legal status.

The emancipatory dimension of the anti-racism embraced by grassroots organizations rests on the opposition to the mechanisms that reproduce racism and is associated with collective alternatives to border regimes grounded in the experiences of racialized migrants. In contrast, the antiracism of large coalitions such as Unteilbar, which is primarily oriented towards combating the racist ideology of populist radical right parties and movements, does not fully challenge the mobility control mechanisms through which border regimes reproduce oppression.

The coalition opposes the climate of "exclusion and antagonism" promoted by the populist radical right and calls for a society where everyone can enjoy human rights. The grievances of Unteilbar do not focus only on border regimes. The coalition makes wide claims for solidarity, social justice and diversity that contested social and political dynamics beyond border regimes. Unteilbar demands equal rights for all the marginalized groups in society.

The coalition does not formulate alternatives to the mobility control mechanisms that racialized activists who mobilize with grassroots organizations identify as producing their oppression. The manifesto for the protest does not invoke universal freedom of movement and the right to stay, which are crucial components of the alternatives solutions to border regimes that grassroots organizations collectively elaborate. Unteilbar claims the right to protection and asylum, which does not entail the opposition to all deportations and camps, which grassroots organizations interpret as among the main mechanisms producing the oppression of migrants. The right to seek and enjoy asylum is premised on the notion of fairness of the asylum processes but is not tied to a positive outcome for all those who claim asylum. Activists who mobilized with grassroots organizations considered the right to asylum as a limited claim. For example, Ester, a German activist who mobilized with Welcome United, told me: "We don't formulate our claims around the right to asylum because it implies that the nation state is allowed to decide if people can be here or not. It's a form of migration control". ${ }^{20}$

Grassroots organizations such as Women in Exile and friends joined the coalition Unteilbar and participated in the protest that took place on 13 October 2018 in Berlin. My interviews with NGOs such as Amnesty International, which was part of Unteilbar, have revealed a tension within the coalition between grassroots organizations and NGOs. While the former suggested framing the coalition's demands through the notion of the right to stay, the latter supported the notion of the right to asylum. ${ }^{21}$ Katya, an 
activist who mobilized with a grassroots organization and who was also involved with Unteilbar explained to me:

Many of the groups thought that the right to asylum was a 30 -year old call. ${ }^{22}$ Many of us aimed to be more radical, more on the left ... but we needed the big organizations for money, visibility and mobilization. This alliance [Unteilbar] is very broad and it cannot fulfil $100 \%$ of the goals of each partner. ${ }^{23}$

Unteilbar opposes the tightening of border regimes as well as the racist and anti-migrant frames that are at the core of the agendas of populist radical right parties and movements. In a context in which the right to asylum is under attack as an anti-migrant and anti-refugee tide sweeps Germany and Europe, Unteilbar defends the right of people fleeing wars and persecution to seek protection in Germany.

Grassroots organizations joined Unteilbar for strategic reasons in view of the rise of populist radical right parties and movements. They give prominence to their opposition to the racist ideology of radical right parties by forming an alliance with large NGOs and trade unions, which organized a large protest on 13 October 2018 in Berlin that received prominent media attention. ${ }^{24}$ Meanwhile, grassroots organizations continued to engage in grassroots anti-racist politics through which they targeted institutional racism and the role of border regimes in reproducing racism. Different dimensions of anti-racism intersect in the grassroots mobilization against border regimes; they are not incompatible although their salience may change over time also in light of strategic decisions made by actors in confronting political and social processes. However, as I have argued in this article, the distinctive feature of grassroots anti-racism is the formulation of alternatives to border regimes that are emancipatory for racialized migrants.

\section{Conclusions}

In recent years we have witnessed spectacular and visible forms of racism in Germany. The successes reaped by populist radical right parties and movements as of 2014 have stimulated the emergence of new coalitions such as Unteilbar, which is an alliance between grassroots organizations, large NGOs, and trade unions.

Grassroots organizations contesting border regimes in Berlin embrace an anti-racism that combats populist radical right parties and movements; GROs strategically give prominence to that dimension of anti-racism in specific contexts such as during the increased social movement activity in 2018. However, following Lentin (2008), I have contended that their antiracism is complex and heterogeneous and comprises other components. In particular, the anti-racism of grassroots organizations reveals how racism is 
a system that oppresses racialized migrants, how it pervades the state, and how border regimes reproduce it.

By grounding their anti-racism in the experiences of racialized migrants, grassroots organizations orient their anti-racist struggle against a system of relations that oppress and dominate migrants on the basis of characteristics, such as race, citizenship and nationality that are seen as inherited and unchangeable (Camfield 2016). Grassroots organizations interpret border regimes as reproducing oppression through mobility control mechanisms. In their struggle against border regimes, grassroots organizations conceive the imbrication between border regimes and racism within the wider historical context in which racial inequalities are being reproduced. This form of anti-racism is a crucial intervention in a context such as the German one in which the role of racism in constructing the German nation has often been expunged from public debates.

Some scholars have emphasized the differences between antifascism and anti-racism (Battacharyya, Virdee, and Winter 2020; Gilroy 1987; Lentin 2008). In particular, antifascism, that is the opposition to the far-right, may underestimate the fact that racism is embedded and diffused in various state institutions, including in states that are not overtly racist (Battacharyya, Virdee, and Winter 2020). I have contributed to this debate by showing that different components of anti-racism can overlap in the mobilization against border regimes. Challenging the racist frames of populist radical right parties and movements can be combined with the struggle against the system of domination and oppression that racist border regimes reproduce. We see these different dimensions of anti-racism in the mobilization of grassroots organizations opposing border regimes.

However, I have argued that grassroots anti-racism, which is geared towards combating racism as a system of domination of racialized migrants, is emancipatory. Grassroots organizations collectively develop alternative solutions to border regimes that challenge the main mechanisms through which the mobility of migrants is controlled and restricted, oppose all deportations and demand residence rights for everyone.

The oppression of racialized migrants is not the exclusive undertaking of populist radical right parties and movements. My findings suggest that the anti-racism of coalitions such as Unteilbar, which is geared towards the opposition of populist radical right parties and movements, does not fully acknowledge the role of border regimes in reproducing racism, the colonial legacy and the pervasiveness of racism as a system of relations based on domination and oppression.

The anti-racist struggle that grassroots organizations in Berlin weave against border regimes is intimately connected to how racialized migrants experience border regimes. Following Bojadžijev's proposal to consider anti-racist struggle as a source of knowledge to understand racism, I have 
showed how their anti-racist struggle produces knowledge about the mechanisms through which border regimes reproduce racism as a system of oppression of racialized migrants.

In his proposal for recalling anti-racism, Hage has emphasized the importance of anti-racism to be "wedded with fantasies for a non-racial society" (Hage 2016). The anti-racism of grassroots organizations that contest border regimes does not simply oppose the mechanisms through which border regimes reproduce racism. It proposes solutions that contribute to the idea of a non-racial society in which the very mechanisms through which border regimes oppress racialized migrants would cease to operate.

\section{Notes}

1. Women in Exile and friends published a call ahead of the protest that is accessible here: https://www.women-in-exile.net/frauen-gemeinsam-gegenrassismus-und-ungerechtigkeit/. Women in Exile and friends is a grassroots feminist and anti-racist organization in which mainly racialized migrant women mobilize.

2. The coalition agreement that paved the way for a government between the Social-Democrats (SPD) and the Christian-Democrats (CDU-CSU) comprised some of the restrictive migration policies that Horst Seehofer implemented in 2018. These policies include the limitations of family reunification for people with the subsidiary protection legal status and the establishment of the Anker centres, which are new all-encompassing receptions centres in which asylum seekers can spend up to 24 months while waiting for their application to be assessed. A translation of the agreement's section regarding migration and asylum is available here: https://oplatz.net/wp-content/uploads/2018/03/ GermanyGrandCoalition-Migration-English-Deutsch.pdf.

3. In their review article, Jasper Muis and Tim Immerzeel emphasize the populist, anti-establishment rhetoric of populist radical right parties and movements as well as their authoritarianism and ethnocentric values which translate into an anti-migrant agenda especially in Western Europe (Muis and Immerzeel 2017).

4. The call for the protest Unteilbar can be found here: https://www.unteilbar.org/ uber-unteilbar/positionen/aufruf-13-10-2018/.

5. Only in May 2021, the German Minister for Foreign Affairs officially recognized the genocide perpetrated in Namibia, more information is available here: https://www.politico.eu/article/germany-recognizes-colonial-herero-namagenocide/.

6. On 7 June 2019, the Federal Parliament adopted the "Orderly Return Law" which made changes to asylum law. Asylum seekers are required to live in a designated reception centre for up to 18 months. During this period they cannot leave the district where the reception centre is located. After 18 months, those who are still waiting for their asylum claim to be processed are sheltered in shared accommodation. Further information regarding these legislative changes is accessible here: https://www.asylumineurope.org/news/ 14-06-2019/germany-controversial-law-package-passes-parliament-1\#: :text= While\%20the\%20current\%20Section\%2047,amendments\%20substantially\% 20extend\%20this\%20period. 
7. Further information about the Anker centres is available here: https://www. asylumineurope.org/sites/default/files/anker_centres_report.pdf.

8. Women in Exile and friends organized the bus tour "Women Breaking Borders" in July and August 2018. Several dozen activists travelled across Germany and organized protests, seminars and other activities to raise awareness against border regimes. For more information see: https://www.women-in-exile.net/ en/category/bustoue2018/.

9. Ethnographic notes taken on 27 July 2018.

10. The full press release is accessible here (in German): https://www.africa-live.de/ demonstration-gegen-alle-abschiebungen-so-11-02-berlin-wedding/.

11. Duldung literally means "toleration" in German.

12. The conditions according to which individuals who hold a duldung can work are accessible here (in German): http://www.bamf.de/EN/Infothek/FragenAntwo rten/ZugangArbeitFluechtlinge/zugang-arbeit-fluechtlinge-node.html.

13. Robert did not possess any document proofing his nationality and feared being deported to a country different from his country of origin.

14. Ethnographic notes taken on 20 June 2018.

15. Interview with Charles, 16 August 2018.

16. The manifesto of Welcome United is accessible here: https://www.welcomeunited.org/en/charta-2/.

17. Manifesto published by the network Welcome United ahead of the anti-racist march scheduled for 30 September in Hamburg, https://www.welcomeunited.org/en/charta-2/.

18. Interview with Carmela, 11 June 2018.

19. Interview with Julia, 19 September 2018.

20. Interview with Ester, 11 September 2018.

21. Interview with a representative of Amnesty International, 3 October 2018.

22. Katya referred to the debates in the early 1990s that resulted in the amendment of the German Constitution and the restriction of the asylum law. See Blay and Zimmermans (1994).

23. Interview with Katya, 21 September 2018.

24. See for example The Guardian, "German march against far right draws huge crowd in Berlin", available at https://www.theguardian.com/world/2018/oct/ 14/german-march-against-far-right-draws-huge-crowds-in-berlin.

\section{Disclosure statement}

No potential conflict of interest was reported by the author(s).

\section{ORCID}

Marco Perolini (D) http://orcid.org/0000-0002-2474-2725

\section{References}

Agamben, G. 1998. Sovereign Power and Bare Life. Stanford, CA: Stanford University Press.

Amnesty International. 2016. Living in Insecurity. How Germany is Failing Victims of Hate Crimes. London: Amnesty International. 
Balibar, E. 1991. "Is There a Neo-Racism?" In Race, Nation, Class: Ambiguous Identities, edited by E. Balibar, and I. M. Wallerstein. London: Verso.

Barker, J. 2017. "Is Multikulti Dead? Angela Merkel and Immigration Politics in Germany." Women Leading Change: Case Studies on Women, Gender, and Feminism 1 (3): 68-82.

Battacharyya, G., S. Virdee, and A. Winter. 2020. "Revisiting Histories of Anti-Racist Thought and Activism." Identities 27 (1): 1-19. doi:10.1080/1070289X.2019. 1647686.

Benček, D., and J. Strasheim. 2016. "Refugees Welcome? A Dataset on Anti-Refugee Violence in Germany." Research \& Politics 3 (4), doi:10.1177/2053168016679590.

Blay, S., and A. Zimmermans. 1994. "Recent Changes in German Asylum law: A Critical Assessment." The American Journal of International Law 88 (2): 361-378.

Boehme, F. 2020. "Reactive Remembrance: The Political Struggle Over Apologies and Reparations Between Germany and Namibia for the Herero Genocide." Journal of Human Rights 19 (2): 238-255. doi:10.1080/14754835.2020.1727729.

Bojadžijev, M. 2020. "Anti-racism as Method." In Routledge International Handbook on Contemporary Racisms, edited by J. Solomos, 193-204. London: Routledge.

Bonnett, A. 2000. Anti-Racism. London: Routledge.

Boulila, S. C., and C. Carri. 2017. "On Cologne: Gender, Migration and Unacknowledged Racisms in Germany." European Journal of Women's Studies 24 (3): 286-293. doi:10. $1177 / 1350506817712447$.

Bulmer, M., and J. Solomos. 2018. "Why Do We Still Talk About Race Today?" Ethnic and Racial Studies 41 (6): 997-1013. doi:10.1080/01419870.2018.1435897.

Camfield, D. 2016. "Elements of a Historical-Materialist Theory of Racism." Historical Materialism 24 (1): 31-70. doi:10.1163/1569206X-12341453.

Casas-Cortes, M., S. Cobarrubias, N. De Genova, G. Garelli, G. Grappi, C. Heller, S. Hess, et al. 2015. "New Keywords: Migration and Borders." Cultural Studies 29 (1): 55-87. doi:10.1080/09502386.2014.891630.

De Genova, N. 2002. "Migrant "Illegality" and Deportability in Everyday Life." Annual Review of Anthropology 31 (1): 419-447. doi:10.1146/annurev.anthro.31.040402. 085432.

De Genova, N. 2005. Working the Boundaries: Race, Space, and 'lllegality' in Mexican Chicago. Durham, NC: Duke University Press.

Diani, M. 1992. "The Concept of Social Movement." The Sociological Review 40 (1): 1-25. doi:10.1111/j.1467-954X.1992.tb02943.x.

El Tayeb, F. 1999. "“Blood is a Very Special Juice": Racialized Bodies and Citizenship in Twentieth-Century Germany." International Review of Social History 44 (7): 149-169. doi:10.1017/S0020859000115238.

Erel, U., K. Murji, and Z. Nahaboo. 2016. "Understanding the Contemporary RaceMigration Nexus." Ethnic and Racial Studies 39 (8): 1339-1360. doi:10.1080/ 01419870.2016.1161808.

Florvil, T. N. 2020. Mobilizing Black Germany: Afro-German Women and the Making of a Transnational Movement. Urbana, IL: University of Illinois Press.

Fontanari, E. 2017. "Looking for Neverland: the Experience of the Group Lampedusa in Berlin and the Refugee Protest of Oranienplatz." In Witnessing the Transition: Moments in the Long Summer of Migration, edited by G. Yurdakul, R. Römhild, A. Schwanhäußer, and B. zur Nieden, 15-35. Berlin, DE: Berlin Institute for empirical Integration and Migration Research (BIM).

Georgi, F. 2019. "The Role of Racism in the European 'Migration Crisis': A Historical Materialist Perspective." In Racism After Apartheid, edited by V. Satgar. Wits 
University Press. Open WorldCat. http://www.oapen.org/download?type= document\&docid $=1004360$.

Gilroy, P. 1987. There Ain't no Black in the Union Jack: The Cultural Politics of Race and Nation. London: Hutchinson.

Goldberg, D. T. 2002. The Racial State. Malden, MA: Blackwell Publishers.

Goldberg, D. T., and J. Solomos. 2002. A Companion to Racial and Ethnic Studies. Malden, MA: Blackwell.

Green, S. 2012. "Much ado About not-Very-Much? Assessing Ten Years of German Citizenship Reform." Citizenship Studies 16 (2): 173-188. doi:10.1080/13621025. 2012.667610.

Hage, G. 2016. "Recalling Anti-Racism." Ethnic and Racial Studies 39 (1): 123-133. doi:10.1080/01419870.2016.1096412.

Hall, S. 1997. Race, the floating signifier. Media Education Foundation Film. Retrieved December 2015, from http://www.mediaed.org/transcripts/Stuart-Hall-Race-theFloating-Signifier-Transcript.pdf.

Hall, S. 2000. "Conclusion: The Multi-Cultural Question." In Un/Settled Multiculturalisms: Diasporas, Entanglements, 'Transruptions', edited by B. Hesse, 209-221. London: Zed Books.

Hamann, U., and S. Karakayali. 2016. "Practicing Willkommenskultur: Migration and Solidarity in Germany." Intersections 2 (4), doi:10.17356/ieejsp.v2i4.296.

Hartz, R. 2019. "The People' and its Antagonistic Other: the Populist Right-Wing Movement Pegida in Germany." In Discourse, Culture and Organization: Inquiries Into Relational Structures of Power, edited by T. Marttila, 223-244. Cham, CH: Springer International Publishing.

Jakob, C. 2016. Die Bleibenden: Wie Flüchtlinge Deutschland seit 20 Jahren verändern (1. Auflage). Ch. Links Verlag.

Johnson, J. C., C. Avenarius, and J. Weatherford. 2006. "The Active ParticipantObserver: Applying Social Role Analysis to Participant Observation." Field Methods 18 (2): 111-134. doi:10.1177/1525822X05285928.

Langa, N. 2015. "About the Refugee Movement in Kreuzberg/Berlin." Movements. Journal for Critical Migration and Border Regime Studies 1 (2).

Lazaridis, L., and M. Veikou. 2017. "The Rise of the Far Right in Greece and Opposition to 'Othering', Hate Speech, and Crime by Civil and Civic Organization." Journal of Civil Society 13 (1): 1-17. doi:10.1080/17448689.2016.1251032.

Lees, C. 2018. "The 'Alternative for Germany': The Rise of Right-Wing Populism at the Heart of Europe." Politics 38 (3): 295-310. doi:10.1177/0263395718777718.

Lentin, A. 2008. "After Anti-Racism?" European Journal of Cultural Studies 11 (3): $311-$ 331. doi:10.1177/1367549408091846.

Lentin, A. 2011. "What Happens to Anti-Racism When We Are Post Race?" Feminist Legal Studies 19 (2): 159-168. doi:10.1007/s10691-011-9174-5.

Mandel, R. E. 2008. Cosmopolitan Anxieties: Turkish Challenges to Citizenship and Belonging in Germany. Durham, NC: Duke University Press.

McGarry, A., M. Tramontano, and J. M. Jasper. 2015. "Scholarly Research on Collective Identities." In The Identity Dilemma: Social Movements and Collective Identity, edited by A. McGarry, and J. M. Jasper, 18-41. Philadelphia, PA: Temple University Press.

Morris, L. 2003. "Managing Contradiction: Civic Stratification and Migrants'rights." International Migration Review 37 (1): 74-100. doi:10.1111/j.1747-7379.2003.tb00130.x.

Muis, J., and T. Immerzeel. 2017. "Causes and Consequences of the Rise of Populist Radical Right Parties and Movements in Europe." Current Sociology 65 (6): 909930. doi:10.1177/0011392117717294. 
Müller, U. A. 2011. "Far Away So Close: Race, Whiteness, and German Identity." Identities 18 (6): 620-645. doi:10.1080/1070289X.2011.672863.

Odugbesan, A. and H. Schwiertz. 2018. "We Are Here to Stay" - Refugee Struggles in Germany Between Unity and Division." In Protest Movements in Asylum and Deportation, edited by S. Rosenberger, V. Stern, and N. Merhaut. http://www. oapen.org/download?type=document\&docid=1002267.

Perolini, M. 2020. "Abolish all Camps in Times of Corona: the Struggle Against Shared Accommodation for Refugees* in Berlin." Interface: A Journal for and About Social Movements 12 (1): 213-224. https://www.interfacejournal.net/wp-content/ uploads/2020/07/Interface-12-1-Perolini.pdf.

Roediger, D. R. 2017. Class, Race, and Marxism. London: Verso.

Rucht, D. 2018. "Mobilization Against Refugees and Asylum Seekers in Germany: A Social Movement Perspective." In Protest Movements in Asylum and Deportation, edited by S. Rosenberger, V. Stern, and N. Merhaut, 185-205. Cham: Springer Open.

Sayyid, S. 2017. "Post-racial Paradoxes: Rethinking European Racism and Anti-Racism." Patterns of Prejudice 51 (1): 9-25. doi:10.1080/0031322X.2016.1270827.

Scheel, S., and P. Ratfisch. 2014. "Refugee Protection Meets Migration Management: Unhcr as a Global Police of Populations." Journal of Ethnic and Migration Studies 40 (6): 924-941. doi:10.1080/1369183X.2013.855074.

Tsianos, V., and S. Karakayali. 2010. "Transnational Migration and the Emergence of the European Border Regime: An Ethnographic Analysis." European Journal of Social Theory 13 (3): 373-387. doi:10.1177/1368431010371761. 